\title{
CHANGES IN THE ULTRASTRUCTURE OF MERISTEMATIC ROOT CELLS OF ALLIUM SATIVUM L. TREATED WITH SELENIUM
}

\author{
SŁAWA GLIŃSKA, BARBARA GABARA \\ Department of Plant Cytology and Cytochemistry, University of Łódź \\ Banacha 12/16, 90-237 Łódź, Poland
}

(Received: September 24, 1999. Accepted: February 1, 2000)

\begin{abstract}
Ultrastructure of meristematic cells of garlic (Allium sativum L.) roots treated with sodium selenate and sodium selenite was assessed using transmission electron microscopy. Both selenium compounds applied at the concentrations: 80,160 and $320 \mu \mathrm{M}$ caused many malformations in the ultrastructure of mitochondria, plastids, endoplasmic reticulum and Golgi apparatus such as deformation in shape and size, disturbances in inner membranes organization, appearance of concentric or parallel arrangement of ER cisternae. Moreover, in the presence of selenium, beside uneven thickening of cell wall, many vacuoles of different dimensions filled with wall-like material even in the vicinity of nucleus were visible. The latter results suggest that selenium not only intensified the synthesis of cell wall material but also inhibited the process of cell wall material deposition. The similarity of all observed ultrastructural changes in garlic root cells after selenium treatment with those appearing after action of other stress factors are discussed.
\end{abstract}

KEY WORDS: ultrastructure, garlic, root cells, selenium.

\section{INTRODUCTION}

Selenium is required for some plant species, called selenium accumulators, as their growth is inhibited in its absence (Trelease and Trelease 1938). However, the similar effect can be seen in these plants at a very high selenium level (Spallholz 1994). On the other hand, the growth of non-accumulator plants can be disturbed in the presence of small selenium amounts (Trelease and Trelease 1939).

Our preliminary observations of garlic roots treated with sodium selenate or selenite indicated that these compounds differently affected dry mass of roots, their growth and mitotic activity (Glińska unpubl.). Moreover, analysis at the ultrastructural level revealed selenium presence mostly in plastids and lower amounts in mitochondria, nucleus, ER, GA, cytoplasm and vacuoles (Glińska and Gabara, in prep.). No data are available concerning selenium influence on ultrastructure of cells.

Therefore, the aim of this work was to establish whether selenium localized in particular organelles affected their ultrastructure.

\section{MATERIAL AND METHODS}

Garlic (Allium sativum L.) belonging to selenium absorbers and tolerating moderate concentrations of selenium was the

\section{Abbreviations used:}

$\mathrm{N}$ - nucleus, GA - Golgi apparatus, $\mathrm{M}$ - mitochondria, $\mathrm{CW}$ - cell wall, P - plastids, ER - endoplasmic reticulum. object of the present studies. The five-day-old adventitious roots growing in sand moistened with tap water in darkness at the temperature of $20^{\circ} \mathrm{C}$ were rinsed with distilled water and treated with aerated aqueous solutions of sodium selenate $\left(\mathrm{Na}_{2} \mathrm{SeO}_{4}\right)$ or sodium selenite $\left(\mathrm{Na}_{2} \mathrm{SeO}_{3}\right)$ at the concentrations of $80,160,320 \mu \mathrm{M}$, for $24 \mathrm{~h}$. The control consisted of plants kept in aerated distilled water.

For ultrastructural analysis roots were fixed in $2 \%$ glutaraldehyde buffered with $0.1 \mathrm{M}$ sodium cacodylate to $\mathrm{pH} 7.5$, for $2 \mathrm{~h}$ at $4^{\circ} \mathrm{C}$. Than, they were rinsed with the same buffer and subsequently postfixed in $1 \%$ osmium tetroxide for $2 \mathrm{~h}$ at $4^{\circ} \mathrm{C}$. The material was prepared for electron microscopy in a standard way i.e. dehydrated in a graded ethanol series and embedded in Epon-Spurrs resin mixture. Ultrathin sections obtained with Ultratome Reichert after staining with uranyl acetate and lead citrate (Reynolds 1963) were examined in Jeol 1010 transmission electron microscope at $80 \mathrm{kV}$.

\section{RESULTS}

Meristematic cells of garlic (Figs 1-2) control plants had a typical ultrastructure. Most of the cells contained little endoplasmic reticulum and its cisternae had no distinct orientation with respect to the cell walls or other cellular structures (Fig. 1). Meristematic cells contained a regular set of cellular organelles i.e., dictyosomes, mitochondria etc. These organelles had a normal appearance and were embedded in granular cytosol (Figs 1-2). In mitochondria, mostly oval or ellipsoid in shape numerous cristae were visible in electron-dense matrix. Plastids were also ellipsoid or oval in shape and single thyla- 

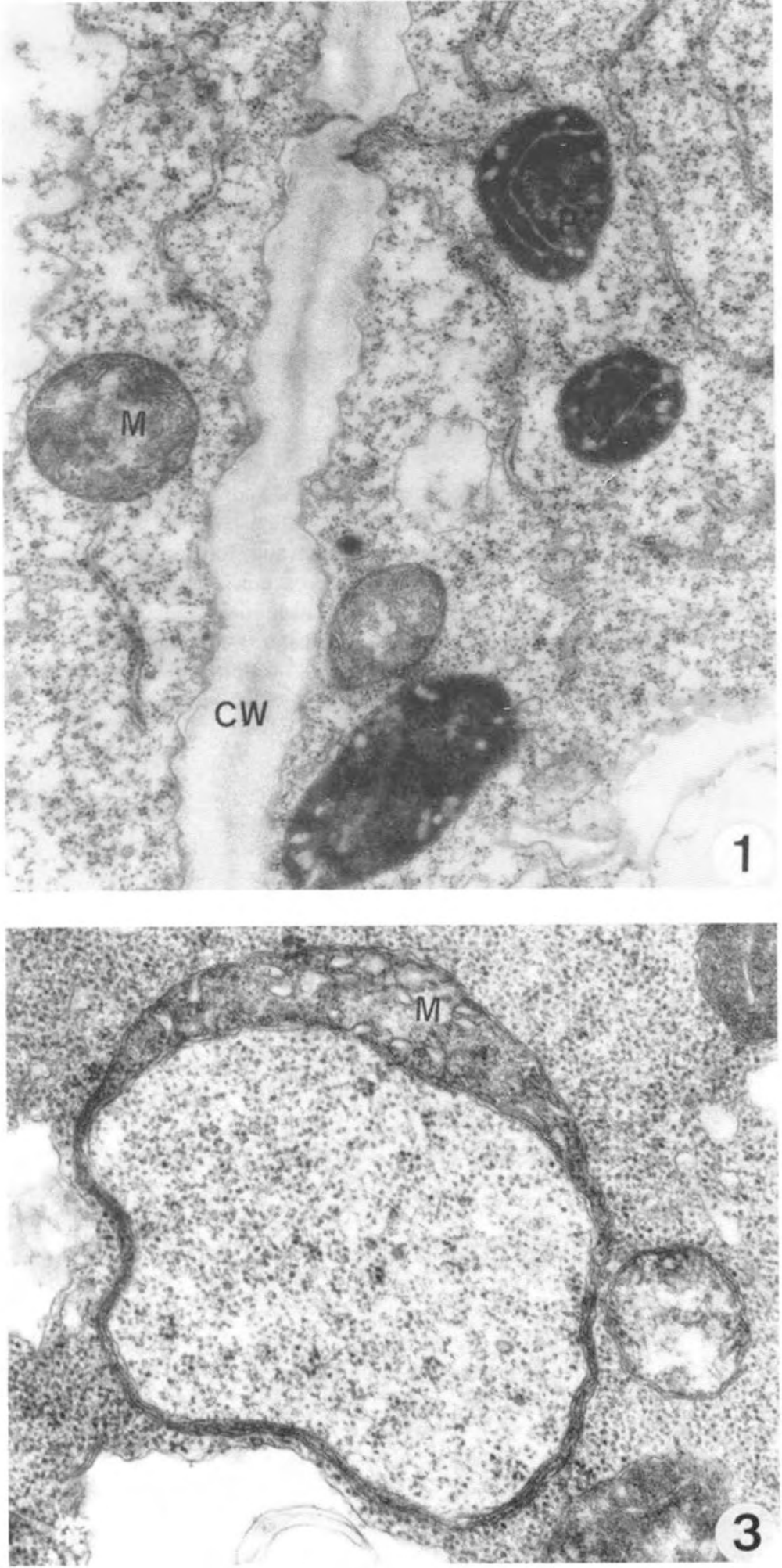
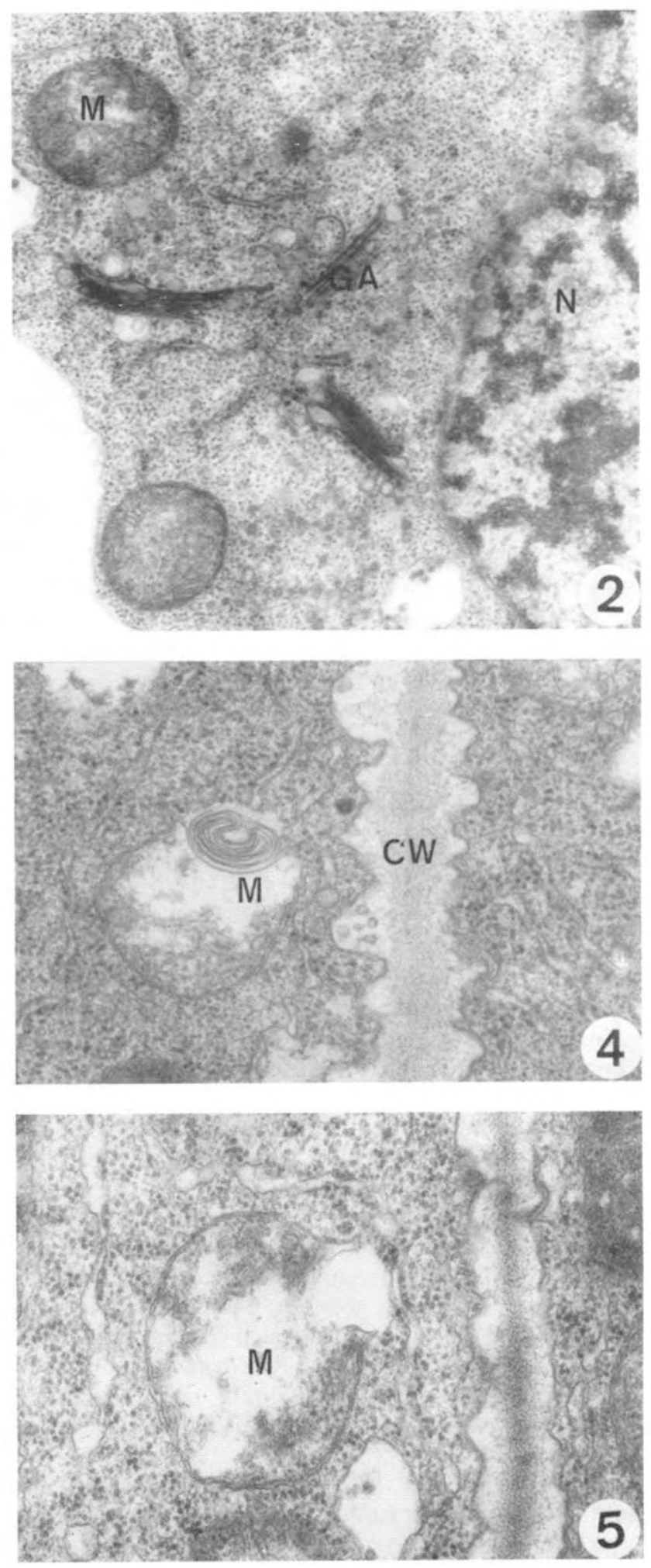

Meristematic cells of garlic root from control (Figs 1-2) and from material treated with selenium for 24 h (Figs 3-20).

Fig. 1. Control root, typical cell ultrastructure. In cytoplasm single cisternae of ER, mitochondria and plastids are visible $(\times 22000)$.

Fig. 2. Control cell with typical organization of Golgi apparatus $(\times 22000)$.

Fig. 3. Fragment of a cell treated with $160 \mu \mathrm{M} \mathrm{Na} \mathrm{SeO}_{4}$, mitochondrium enlarged, unusual in shape $(\times 36000)$.

Fig. 4. Mitochondrium with invagination of a membrane, $80 \mu \mathrm{M} \mathrm{Na}_{2} \mathrm{SeO}_{4}(\times 36000)$.

Fig. 5. Mitochondrium with partially broken membrane, $80 \mu \mathrm{M} \mathrm{Na} 2 \mathrm{SeO}_{3}(\times 36000)$. 
koids were seen in them (Fig. 1). The cell wall, homogenous in structure, was uniformly thick (Fig. 1).

In comparison with control material, the treatment with both selenium compounds, at all used concentrations, caused (Figs 3-20) many changes in the ultrastructure of meristematic cells. It should be stressed, that the number and type of changes were similar both in the cells treated with sodium selenate and sodium selenite. Moreover, there was no correlation between the number and type of changes and the selenium concentration. Therefore, most of the malformations in cell ultrastructure described below were characteristic for both inorganic selenium compounds at all tested concentrations.

Mitochondria underwent noticeable modifications (Figs 35). In some cells enlarged mitochondria, irregular in shape, appeared (Fig. 3). In numerous mitochondria the reduction in number of cristae and local clarification of matrix were observed (Figs 4-5). Very often invaginations of membranes or their appearance in circular form (Fig. 4) were seen in mitochondrial matrix. Sometimes disruptions of outer mitochondrial membrane (Fig. 5) were also observed. Although the bulk of mitochondria revealed the ultrastructural changes described above, in many of them only after treatment with sodium selenate numerous and swollen cristae were visible in condensed matrix (Figs 18, 20).

Some changes were noticed in the ultrastructure of plastids (Figs 6-7). A part of the plastids was characterised by a condensed stroma and lack of thylakoids. Occasionally there appeared enlarged plastids deformed in shape and exhibiting light area filled with cytoplasmic material (Fig. 6). In many cells, plastids cubic in shape were also observed (Fig. 7).

The characteristic modifications were visible in the ultrastructure of endoplasmic reticulum (Fig. 8-10). ER cisternae more aboundant in the presence of selenium were often arranged parallel to cell wall (Fig. 8), their concentric organization was also observed frequently (Fig. 9). Sometimes single ER cisternae connected with vesicles, various in shape and dimensions, filled with electron-dense granules were visible in the cells (Fig.10).

The selenium treatment was responsible for considerable modifications in the ultrastructure of Golgi apparatus (Figs $11-13,17,20$ ). Among them the reduction in a number of cisternae per single dictyosome (Fig. 11), an increase in a number of vesicles originating from dictyosomes (Figs 12-13) were observed most frequently. The vesicles, but mostly vacuoles surrounding GA were filled with fibrillar material resembling cell wall material (Figs 11, 12, 17,18). The disrupted (Fig. 12) or deformed Golgi cisternae with numerous membrane invaginations were quite often seen (Fig. 13). Occasionally cubic (Fig. 20) or concentric (Fig. 17) dictyosomes were found.

In addition to all the above ultrastructural changes, due to the tratment with both selenium compounds, in the root cells appeared also multivesicular bodies (Fig. 14), myelinous figures (Fig. 15) and membranous structures (Fig. 16). The latter structures were sometimes so big that they occupied a large area of the cell.

Meristematic cell walls of roots treated with selenium underwent noticeable modifications (Figs 17-20). The local thickenings of cell wall were frequently formed (Fig. 18) thus the wall became wavy and heterogeneous in structure (Fig 18-19). The vacuoles varying in shape and size filled with wall-like material occurred not only in the vicinity of the cell wall (Fig. 19) but also close to the nucleus (Fig. 20).

\section{DISCUSSION}

Ultrastructural changes observed in garlic root cells after selenium treatment, had been described in many plants after different stress factors (Vartapetian and Zakhmilova 1990; Woźny et al. 1995; Kovacs 1997; Molas 1997; Doncheva 1998; Krzesłowska 1998). Among them mitochondria and plastids abnormal in shape and size were common. In deformed and enlarged mitochondria disturbances in their inner organisation appeared. Such malformations in mitochondria were reported after anoxia (Vartapetian and Zakhmilova 1990), chilling and irradiation (Kovacs 1997), as well as, after various metal treatments: copper (Doncheva 1998), lead (Woźny et al. 1995; Krzesłowska 1998) and nickel (Molas 1997). The disturbances in plastid ultrastructure included: bent and dilated thylakoids after water deficiency (Pastor et al. 1999) or numerous vesicles after lead treatment (Krzesłowska 1998). Analysis of all the above changes indicated that most of them are common for all the studied stress factors. Only concentric membranes within mitochondria of garlic root cells seem to be specific for selenium treatment.

The increase in number of ER cisternae is universal cell response to stress factors i.e. oxygen deficiency (Vartapetian and Zakhmilova 1990) or exposure to heavy metals (Woźny 1998). In Čiamporowa's and Mistrik's (1993) opinion the more numerous ER cisternae become involved in synthesis of stress proteins. The swollen parts of ER cisternae observed in root cells treated with selenium could contain such proteins. On the other hand, ER appears also to be responsible for isolation of toxic ions (Woźny et al. 1995; Kocjan et al. 1996). The presence of selenium electron-dense deposits in lumen of ER cisternae in root cells of garlic treated with selenium (Glińska and Gabara, in prep.) seems to prove an involvement of the higher number of ER cisternae in immobilization of this ion.

Selenium affected the ultrastructure of the Golgi apparatus. Similar disturbances were seen in the presence of brefeldin A (Robinson et al. 1997) and monensin (Cunningham and Hall 1986). These inhibitors of secretory process caused a reduction in number of cisternae per dictyosom and increase in size of vesicles released from GA. Similar effects were attributed to metals such as aluminium (Eleftheriou et al. 1993), copper (Doncheva 1998) and lead (Krzesłowska 1998). Moreover, in case of the latter metal the presence of cup-shaped dictyosomes (Woźny et al. 1995; Krzesłowska 1998) similar to those described after selenium treatment were also formed. The appearance of all the mentioned above changes in root cells suggests that selenium like lead more strongly affected GA than other metals did.

Uneven cell wall thickenings observed in garlic root cells were also seen in other plants after treatment with such metals as aluminium (Eleftheriou et al. 1993), cadmium (Heumann 1987) and lead (Krzesłowska 1998; Wierzbicka 1998). The wall alterations seem to indicate disturbances of processes involved in synthesis and/or deposition of wall material. The presence of many dictyosomes surrounded by large vacuoles filled with cell wall-like material provide evidence that the synthesis of cell wall material was not inhibited, but even stimulated by selenium. Moreover, uneven cell wall thickenings observed in root cells seem to suggest that selenium disturbed the deposition of wall material. Uneven thickenings of cell wall in meristematic cells of Allium cepa after treatment with high doses of lead in Wierzbicka's (1998) opinion suggests an intensified synthesis of cell wall matrix material, but on the other hand, also inhibited or disturbed the 

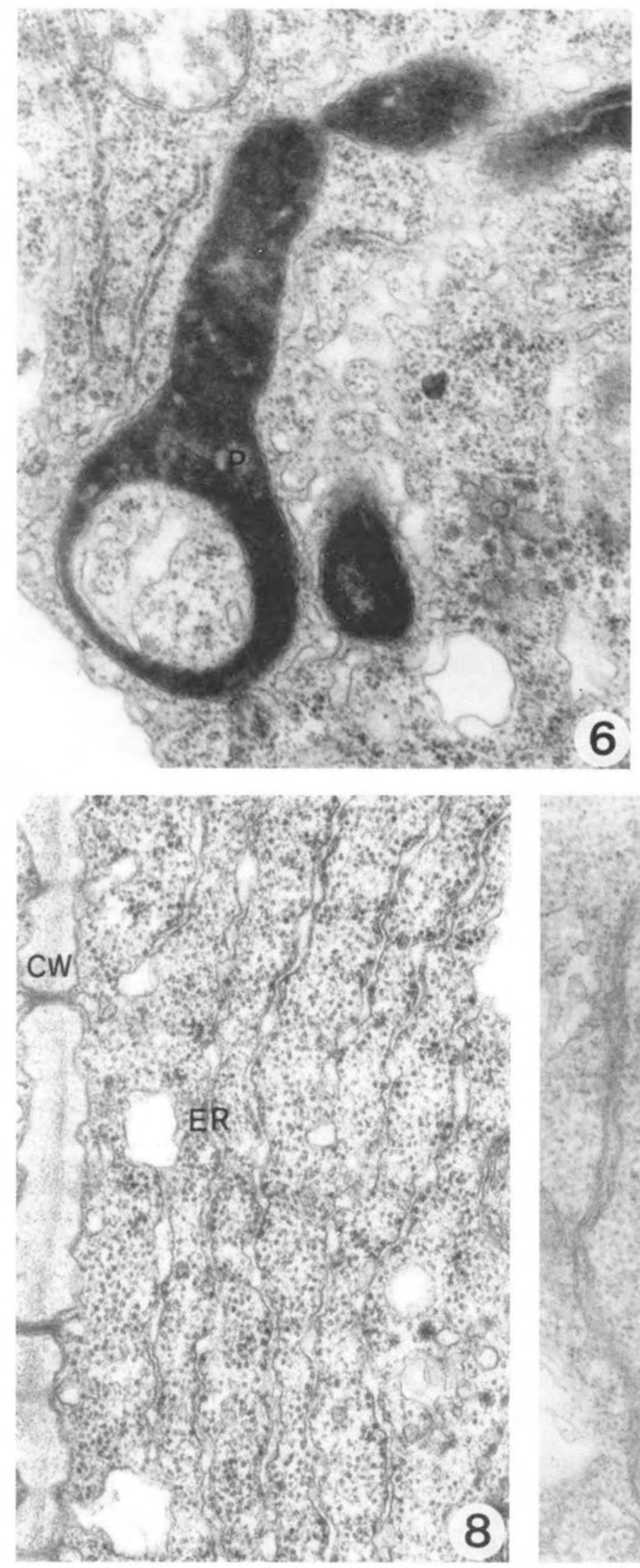
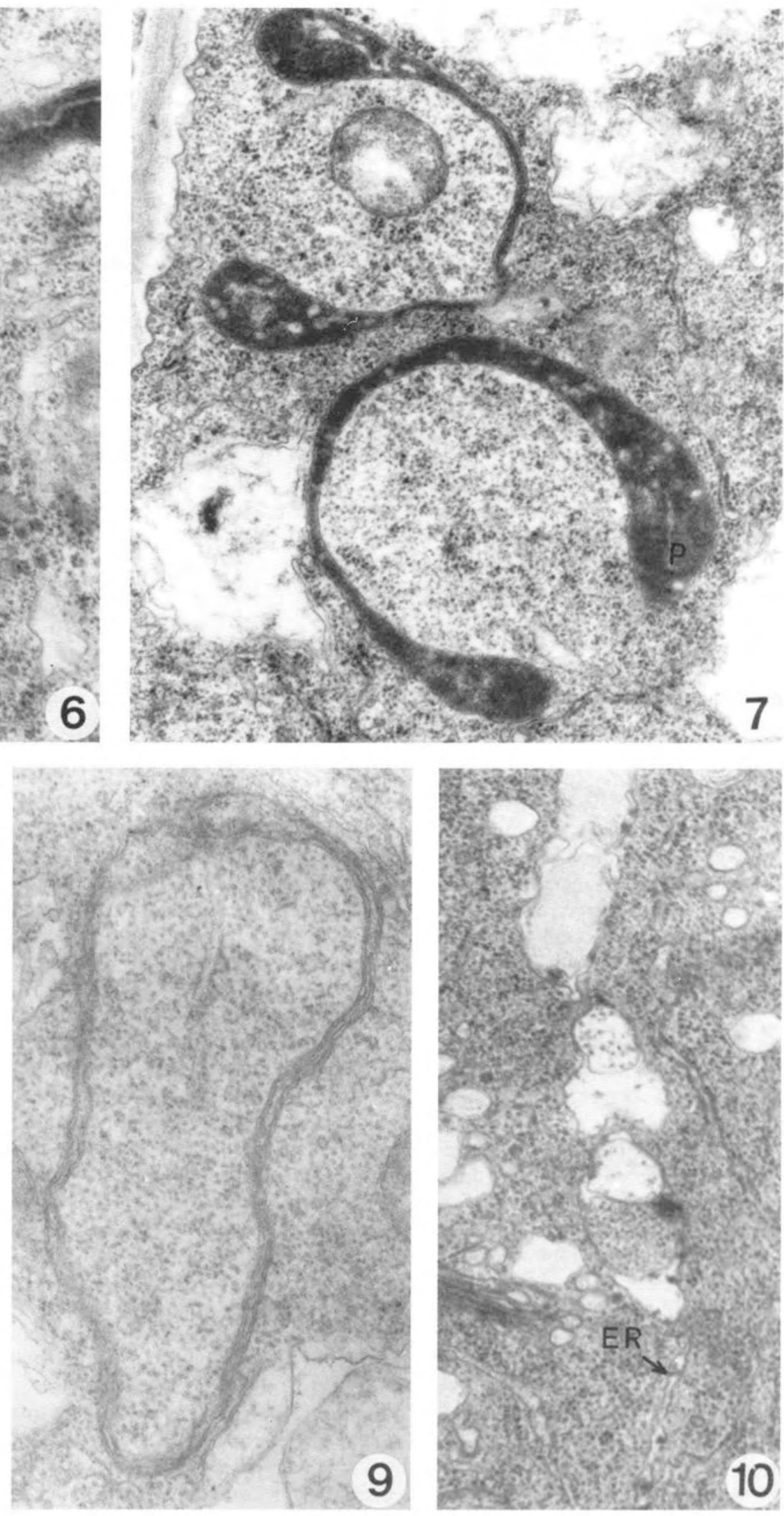

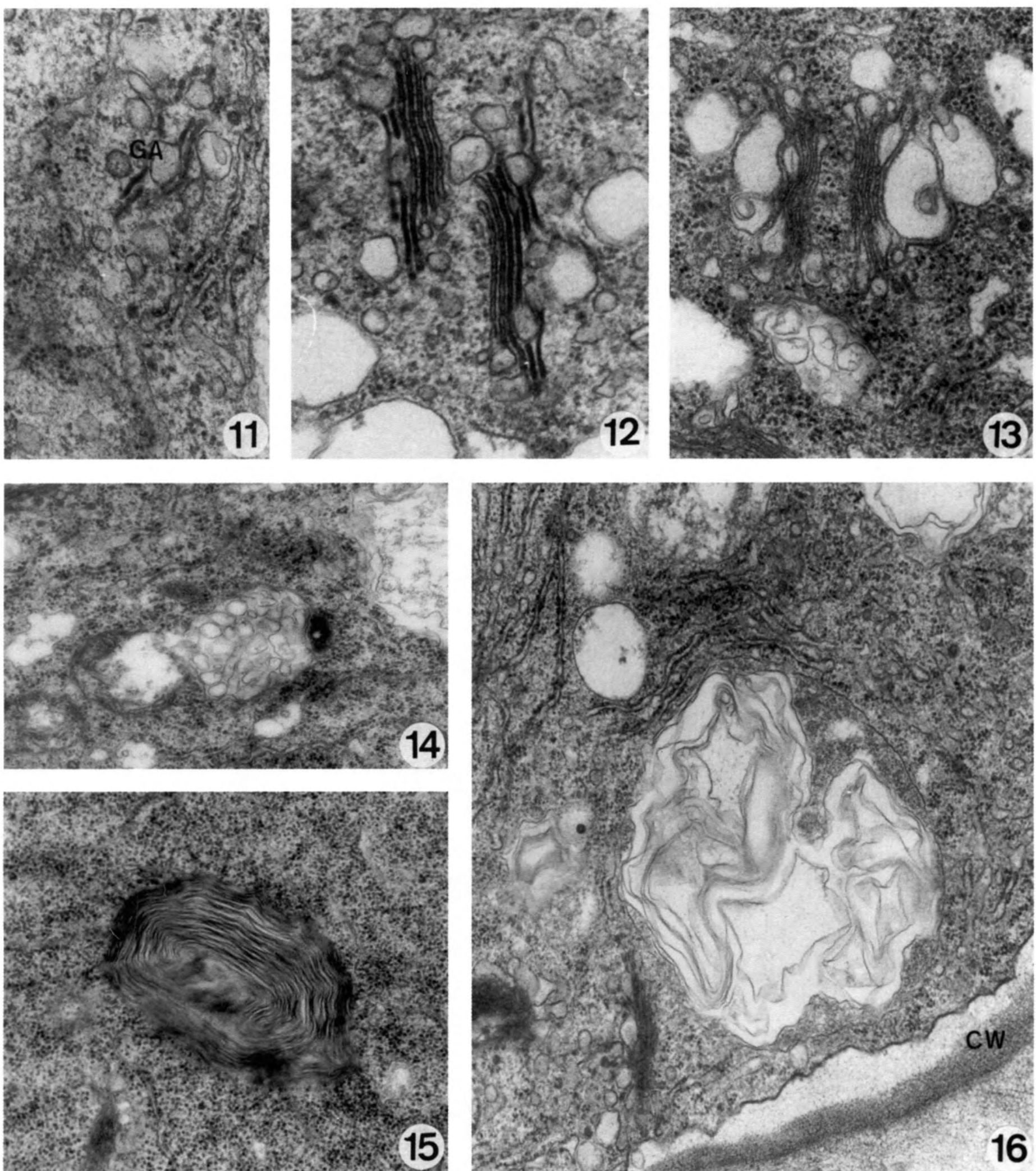

Fig. 11. Golgi apparatus with few cisternae, among them vesicles with cell wall-like material, $80 \mu \mathrm{M} \mathrm{Na} 2 \mathrm{SeO}_{4}(\times 45000)$.

Fig. 12. Divided cisternae of dictyosome, $80 \mu \mathrm{M} \mathrm{Na} 2 \mathrm{SeO}_{4}(\times 45000)$.

Fig. 13. High number of vesicles originating from dictyosomes, and vacuoles surrounding GA membrane invaginations inside the vacuoles, $80 \mu \mathrm{M} \mathrm{Na} \mathrm{SeO}_{4}(\times 45000)$.

Fig. 14. Multivesicular body in cytoplasm of a cell treated with $320 \mu \mathrm{M} \mathrm{Na} 2 \mathrm{SeO}_{3}(\times 30000)$.

Fig. 15. Myelin figure in cytoplasm of a cell treated with $80 \mu \mathrm{M} \mathrm{Na} \mathrm{SeO}_{4}(\times 30000)$.

Fig. 16. Vacuole filled with numerous membranes, $320 \mu \mathrm{M} \mathrm{Na} 2 \mathrm{SeO}_{3}(\times 30000)$. 

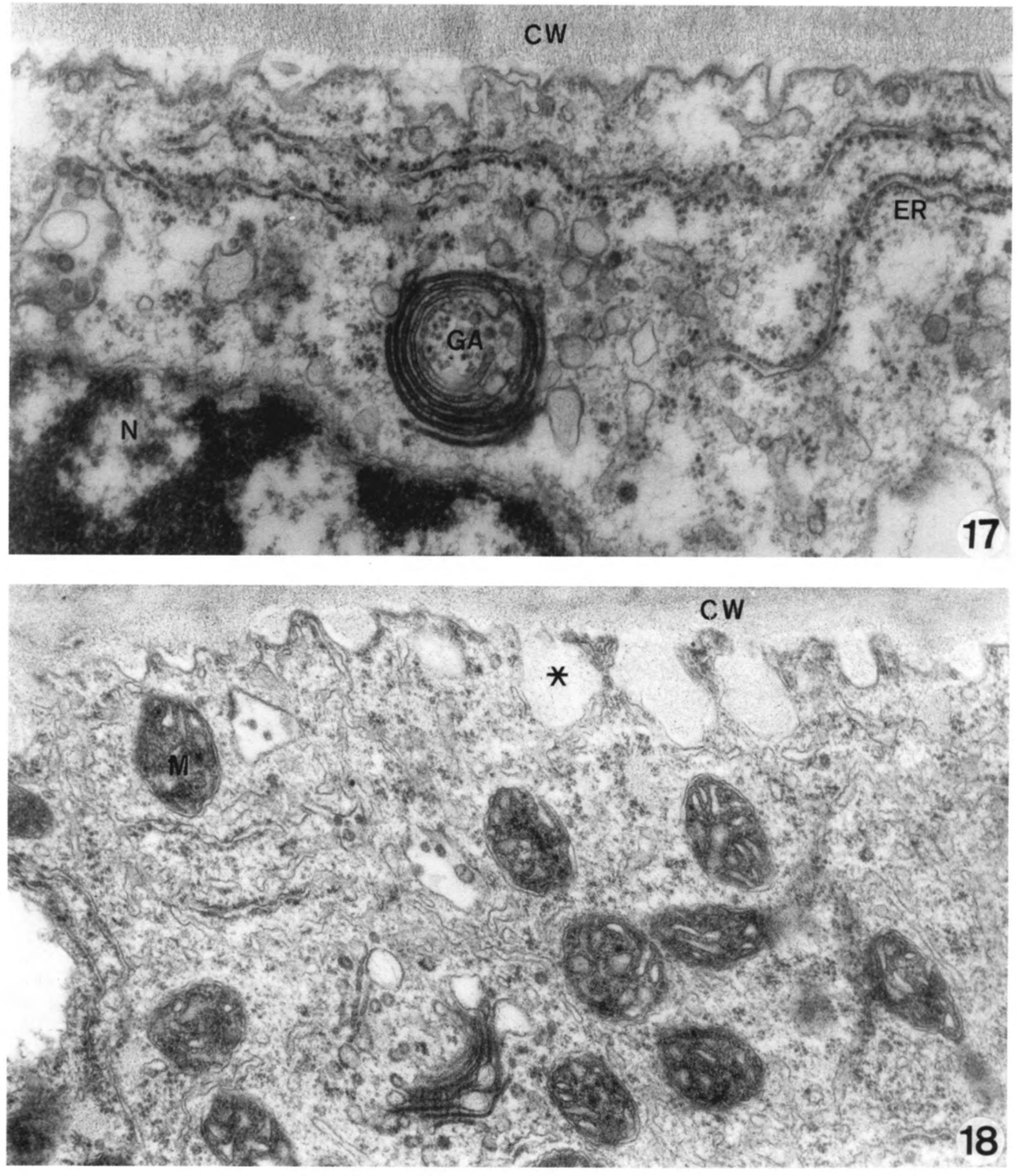

Fig. 17. Fragment of meristematic cell with Golgi apparatus, circular in shape. Typical structure of cell wall, $320 \mu \mathrm{M} \mathrm{Na} 2 \mathrm{SeO}_{4}(\times 36000)$.

Fig. 18. Numerous invaginations of plasma membrane filled with wall-like material, $320 \mu \mathrm{M} \mathrm{Na}_{2} \mathrm{SeO}_{4}(\times 36000)$. 

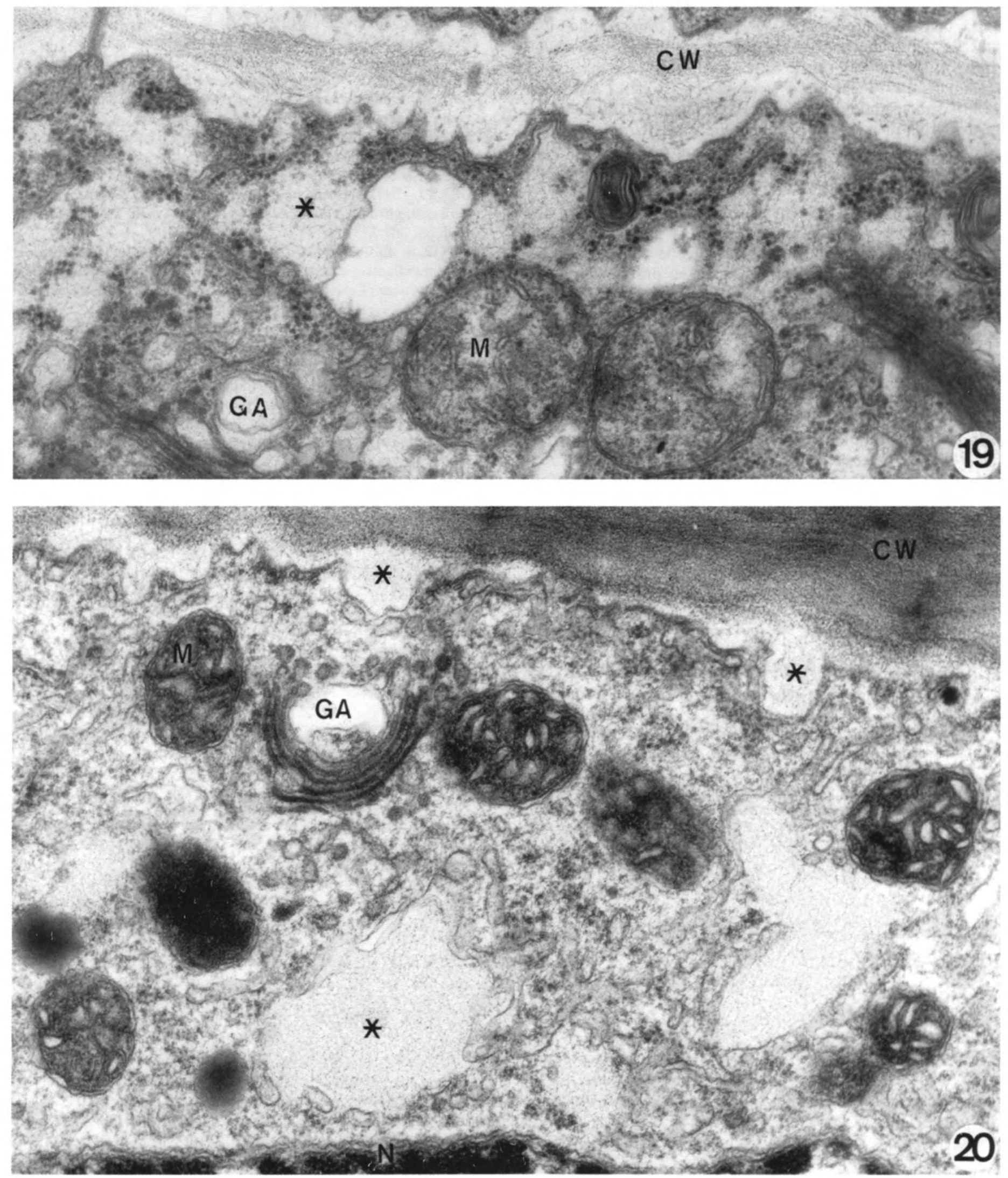

Fig. 19. Uneven thickening of cell wall, in its vicinity many vacuoles filled with wall-like material (asterisk), $320 \mu \mathrm{M} \mathrm{Na} 2 \mathrm{SeO}_{3}(\times 45000)$. Fig. 20. Invaginations of plasma membrane filled with fibrillar material (asterisk). The same type of material in large vacuoles near nucleus. Cubic form of Golgi apparatus, $320 \mu \mathrm{M} \mathrm{Na} 2 \mathrm{SeO}_{4}(\times 45000)$. 
process of its deposition. The appearance of vacuoles filled with cell wall-like material in the vicinity of the nucleus in garlic cells seems to support Wierzbicka's (1998) opinion that lack of microtubules was responsible for disturbed vacuole transport to the cell wall. Experiments on Chara vulgaris (Heumann 1997) and Lilium longiflorum (Röderer and Reiss 1988) demonstrating the disturbed arrangement of cellulose microfibrills in presence of metals indicate a similar conclusion. However, contrary to the results on onion treated with lead (Wierzbicka 1988) no information on selenium affecting microtubles is avalaible.

Cell wall formation depends partly on functioning of the dictyosomes; they in turn are controlled by ion balance (Cunninghame and Hall 1986). Such conclusion comes from experiments with $\mathrm{LaCl}_{3}$. Irregularities in the profile of plasma membrane might indicate vesicle fusion but no cell wall extension in presence of this reagent. After chelator treatment vesicles were prominent in the cytoplasm and the plasma membrane regained a regular profile (Cunninghame and Hall 1986). In light of these data it cannot be excluded that disturbances in cellular ion balance could be responsible for cell wall malformations in selenium presence.

In conclusion, both selenium compounds caused numerous ultrastructural changes in garlic meristematic cells. The reason of their appearance seems to be complex and therefore difficult to determine. We hope that further studies will help us to put more light on these problems. However, the comparison of all observed changes with those caused by other stress factors indicates that cell response to various stresses is similar.

\section{LITERATURE CITED}

ČIAMPOROWA M., MISTRIK J. 1993. The ultrastructural response of root cells to stresfull conditions. Environ. Exp. Bot. 33: 11-26.

CUNNINGHAME M.E., HALL J.L. 1986. The effect of calcium antagonists and inhibitors of secretory processes on auxin-induced elongation and fine structure of Pisum sativum stem segments. Protoplasma 133: 149-159.

DONCHEVA S. 1998. Copper-induced alterations in structure and proliferation of maize root meristem cells. J. Plant Physiol. 153: 482-487.

ELEFTHERIOU P.E., MOUSTAKAS M., FRAGISKOS N. 1993. Aluminate - induced changes in morphology and ultrastructure of Thinopyrum roots. J. Exp. Bot. 44: 427-436.
HEUMANN H.G. 1987. Effects of heavy metals on growth and ultrastructure of Chara vulgaris. Protoplasma 136: 37-48.

KOCJAN G., SAMARDAKIEWICZ S., WOŹNY A. 1996. Regions of lead uptake in Lemna minor plants and localization of this metal within selected parts of the root. Biol. Plant. 38: 107-117.

KOVACS E. 1997. Effect of chilling and irradiation on the ultrastructure of the membranes and mitochondria of fruits and vegetables. Acta Alimentaria 26: 359-381.

KRZESŁOWSKA M. 1998. Cytochemiczny i ultrastrukturowy obraz komórki wierzchołkowej splątka Funaria hygrometrica Hedw. rosnącego w obecności ołowiu w podłożu. PhD Thesis UAM, Poznań.

MOLAS J. 1997. Ultrastructural response of cabbage outer leaf mesophyll cells (Brassica oleracea L.) to excess of nickel. Acta Soc. Bot. Pol. 66: 307-317.

PASTOR A., LÓPEZ-CARBONELL M., ALEGRE L. 1999. Abscisic acid immunolocalization and ultrastructural changes in water-stressed lavender (Lavendula stoechas L.) plants. Physiol. Plant. 105: 272-279.

REYNOLDS S.S. 1963. The use of lead citrate of high $\mathrm{pH}$ as an electron-opaque stain in electron microscopy. J. Cell Biol. 17: 208-212.

ROBINSON D.G., BAÜMER M., HINZ G., HOHL I. 1997. Ultrastructure of the pea cotyledon Golgi apparatus: origin of dense vesicles and the action of brefeldin A. Protoplasma 200: 198-209.

RÖDERER G., REISS H.D. 1988. Different effects of inorganic and thriethyl lead on growth and ultrastructure of lily pollen tubes. Protoplasma 144: 101-109.

SPALLHOLZ J.E. 1994. On the nature of selenium toxicity and carcinostatic activity. Free Rad. Biol. Med. 17: 45-64.

TRELEASE S.F., TRELEASE H.M. 1938. Selenium as a stimulating and possibly essential element for indicator plants. Am. J. Bot. 25: 372-380.

TRELEASE S.F., TRELEASE H.M. 1939. Physiological differentiation in Astragalus with reference to selenium. Am. J. Bot. 26: 530535.

VARTAPETIAN B.B., ZAKHMILOVA N.A. 1990. Ultrastructure of wheat seedling mitochondria under anoxia and postanoxia. Protoplasma 156: 39-44.

WIERZBICKA M. 1988. Phragmoplast microtubules - their role in the formation of cell plate. Inst. Phys. Conf. Ser. 93: 501-502.

WIERZBICKA M. 1998. Lead in the apoplast of Allium cepa L. root tips - ultrastructural studies. Plant Sc. 133: 105-119.

WOŹNY A. 1998. Ołów w roślinach - wnikanie, rozmieszczenie, reakcje. Zesz. Nauk. Kom. Czowiek i srodowisko PAN 21: 171-180.

WOŹNY A., IDZIKOWSKA K., SAMARDAKIEWICZ S., KRZESŁOWSKA M. 1995. Ołów a ultrastruktura komórki. In: Ołów w komórkach roślinnych. Pobieranie, reakcje, odporność. Woźny A. (red.) SORUS, Poznań.

\section{ZMIANY W ULTRASTRUKTURZE KOMÓREK MERYSTEMATYCZNYCH KORZENI ALLIUM SATIVUM L. TRAKTOWANYCH SELENEM}

\section{STRESZCZENIE}

Badano ultrastrukturę komórek merystematycznych korzeni czosnku (Allium sativum L.) traktowanych roztworami selenianu i seleninu sodu w stężeniach $80,160,320 \mu \mathrm{M}$ przy użyciu transmisyjnego mikroskopu elektronowego. Dwa testowane związki selenu powodowały wiele zmian w ultrastrukturze mitochondriów, plastydów, siateczki śródplazmatycznej i aparatu Golgiego np. zmiany wielkości i kształtu, zakłócenia organizacji błon wewnętrznych, równoległy lub koncentryczny układ licznych cystern ER. Ponadto, w obecności selenu następowało nierównomierne grubienie ściany komórkowej. Obserwowano także liczne wakuole wypełnione materiałem do budowy ściany komórkowej nawet w pobliżu jądra. Otrzymane wyniki sugerują, że selen nie tylko wzmaga syntezę materiałów ściany komórkowej ale także modyfikuje proces ich odkładania. W niniejszej pracy dyskutowano podobieństwo opisanych zmian w ultrastrukturze komórek czosnku traktowanych selenem z obserwowanymi po działaniu innych czynników stresowych. 